\title{
Stabilization of Indian Fly Ashes with Soils, Cement, and Randomly Oriented Fibers
}

\author{
Shenbaga R. Kaniraj, V. Gayathri and V.G. Havanagi
}

\begin{abstract}
Experimental studies were carried out on fly ashes from two Indian thermal power plants, namely Rajghat and Dadri, with the aim of improving the utilization of fly ash in geotechnical engineering applications. It was attempted to improve the engineering performance of fly ash by several means such as by mixing fly ash with soils, cement, and polyester fibers. The research program included the study of: a) physical properties, chemical composition and morphology of the fly ashes; b) compaction, strength, and permeability characteristics of the fly ashes and fly ash-soil mixtures; c) compaction and strength characteristics of fly ash-soil mixtures stabilized with fibers alone, with cement alone, and with both cement and fibers. Results showed that addition of fly ash to soils would result in lighter and stronger fills. Fiber inclusions increased the strength of fly ash-soil specimens significantly and altered their behaviour from brittle to ductile. Even small cement contents increased the strength of the fly ash-soil mixtures significantly. With higher cement contents of up to $18 \%$ it was possible to prepare fly ash-cement design mixes that satisfied the strength criteria for pavement base courses.
\end{abstract}

Keywords: Fiber reinforcement, Fly ash, Stabilization, Waste utilization

\section{INTRODUCTION}

I ndia is heavily dependent on thermal power generation for electricity. The coal used as fuel has high ash content. India currently produces more than 130 MT of fly ash annually which in another ten years could rise to 600 MT. To improve the utilization of fly ash, India first commenced a Fly Ash Mission and then a Fly Ash Utilization Program. Utilization of fly ash increased from 1 MT in 1993-94 to 60 MT in 2006-07. The authors carried out a series of experimental studies on fly ashes from two Indian thermal power plants, namely Rajghat and Dadri, with the broad aim of improving the utilization of fly ash in geotechnical engineering applications. The behavior of fiber reinforced coarse grained soils has been investigated by several researchers. According to Gray [1], Brown and Sheu [2], Waldron [3], Wu and Erb [4], and Wu et al [5], plant roots increase the shear strength of the soil significantly and also increase the stability of natural slopes. The root concentration varies from $0.2 \%$ to $1 \%$ depending on the plant type and the increase in strength varies from $29 \%$ to $98 \%$. According to McGown et al [6] the fiber reinforced soil comes under the category of ply soil in which the inclusions are extensible and the ratio of the reinforcement modulus to the unreinforced soil modulus is less than 3000 . The other category called the reinforced earth, has inextensible inclusions and modulus ratio more than 3000. Fibers are of two types namely, natural and synthetic. The important properties of fibers are tensile strength, modulus of elasticity, elongation at break, and specific gravity. The thickness, length, and aspect ratio of fibers are the other important parameters in fiber reinforced soil. Rehsi [7] and Vasan [8] have summarized the properties of different synthetic and natural fibers. In oriented fiber reinforced soil, the fibers are placed in specific direction or at specific inclination to the plane of shear failure. Gray and Ohashi [9], Shewbridge and Sitar [10], and Bauer and Fatani [11] have carried out laboratory tests on oriented fiber reinforced sands and silty sands. In randomly distributed fiber reinforced soil, the fibers are mixed with the soil and compacted in a way that the fibers are oriented in various directions randomly. Hoare [12], Maher [13], Gray and Maher [14], Maher and Gray [15], and Charan [16], have carried out triaxial compression tests on randomly oriented fiber reinforced soil. The information available on the effect of fibers on the behaviour of fly ashes is scanty. Chakraborty and Dasgupta [17] carried out experiments on fly ash collected from Kolaghat thermal power station. The authors attempted to improve the engineering behavior of the fly ashes by several means such as mixing fly ash with other soils, cement, and fibers. The paper presents the salient features and results of the different aspects of the studies: a) physical properties of the fly ashes; b) compaction, strength, and permeability characteristics of the fly ashes and fly ash-soil mixtures; c) compaction and strength characteristics of fly ashes stabilized with polyester fibers alone, with cement alone, and with both cement and fibers. More details can be obtained from the authors' other publications [18]-[26].

Shenbaga R. Kaniraj is with the Universiti Malaysia Sarawak, 94300, Kota Samarahan, Sarawak, Malaysia. (phone: +6082583225; fax: +6082583410; e-mail: rkjshenbaga@feng.unimas.my).

V. Gayathri is with the itm University, Sector 23A, Gurgaon, 122017, India. (email: vgayathri@itmindia.edu)

V.G. Havanagi is with the Central Road Research Institute, Mathura Road, New Delhi, 110020, India. (email: vasant.crri@nic.in) 


\section{FLY ASHES}

Fly ashes were collected in dry condition from the electrostatic precipitators of the Rajghat and Dadri thermal power stations in New Delhi. The scanning electron micrographs (SEM) of the two fly ashes are shown in Figure 1. The fly ashes consisted of spherical particles and had a porous structure. Table 1 shows the results of the tests for physical properties, geotechnical classification, and chemical composition of the two fly ashes. Based on their chemical composition and ASTM C 618 specifications [27], the two the fly ashes were classified as class $F$ and pozzolanic materials.
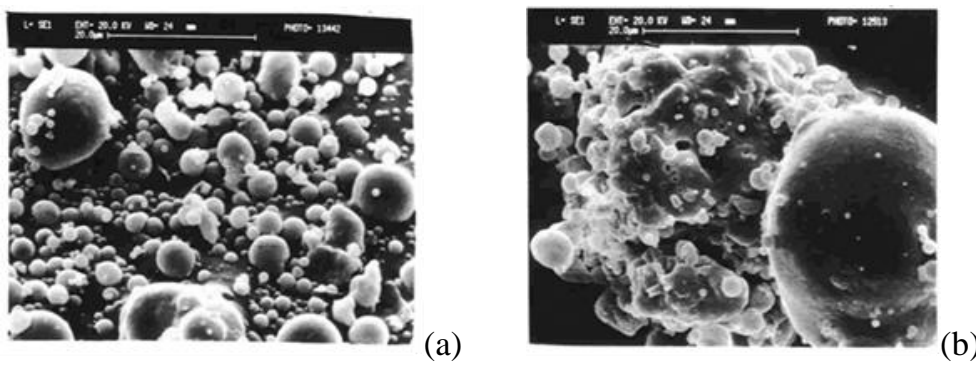

Figure 1 SEM of (a) Dadri and (b) Rajghat fly ashes [23]

Table 1 Physical properties, grain size, Atterberg limits and chemical composition of the fly ashes [26]

\begin{tabular}{l|cc|l|cc}
\hline \multirow{2}{*}{ Properties } & \multicolumn{2}{|c|}{ Fly ash } & \multirow{2}{*}{ Composition } & \multicolumn{2}{c}{ Fly ash } \\
\cline { 2 - 3 } & Dadri & Rajghat & & Dadri & Rajghat \\
\hline Specific gravity, $G$ & 2.2 & 2.19 & Silica $\left(\mathrm{SiO}_{2}\right)$ & 60.12 & 61.21 \\
Loss on ignition, \% & 0.4 & 1.4 & Alumina $\left(\mathrm{Al}_{2} \mathrm{O}_{3}\right)$ & 30.16 & 30.07 \\
Specific surface area, $\mathrm{cm}^{2} / \mathrm{g}$ & 3520 & 4020 & Iron oxide $\left(\mathrm{Fe}_{2} \mathrm{O}_{3}\right)$ & 6.36 & 4.17 \\
Grain size distribution & & & Lime $(\mathrm{CaO})$ & 1.00 & 0.10 \\
Fine sand, 0.475-0.075 mm, \% & 5 & 20 & Magnesia $(\mathrm{MgO})$ & 0.53 & 0.40 \\
Silt size, $0.075-0.002 \mathrm{~mm}, \%$ & 82 & 77 & Titania $\left(\mathrm{TiO}_{2}\right)$ & -- & 2.60 \\
Clay size, $<0.002 \mathrm{~mm}, \%$ & 13 & 3 & Soda $\left(\mathrm{Na}_{2} \mathrm{O}\right)$ & 0.06 & $<0.01$ \\
Uniformity coefficient, $C_{u}$ & 4.82 & 5.65 & Potash $\left(\mathrm{K}_{2} \mathrm{O}\right)$ & 0.007 & 0.02 \\
Atterberg limits & & & Sulphates $\left(\mathrm{SO}_{3}\right)$ & 0.10 & $<0.01$ \\
Liquid limit, $w_{p}, \%$ & 30.5 & $48-50$ & & & \\
Plastic limit. $w_{l}, \%$ & $\mathrm{NP}$ & $\mathrm{NP}$ & & & \\
\hline
\end{tabular}

From the results of grain size distribution and Atterberg limits, both the fly ashes were classified as ML type belonging to the non-plastic silt category.

\section{FLY ASH-SOIL MIXTURES}

\section{A. Rajghat Fly Ash-Soil Mixture}

The Rajghat fly ash was mixed with locally available soils silt and sand separately in different proportions. The details of specific gravity and grain sizes of the two soils are shown in Table 2. Light weight (Proctor) compaction tests were carried out to determine the optimum moisture content (OMC) and maximum dry density (MDD) of the fly ash-soil mixtures. Unconfined compression tests (on 37.7 x $73.5 \mathrm{~mm}$ cylindrical samples) and direct shear tests (on 60 x 60 x $20 \mathrm{~mm}$ samples) were carried out on fly ash-soil mixture samples prepared at their respective OMC and MDD. Table 3 shows the results of the compaction tests, unconfined compressive strength (UCS) and direct shear tests $(c, \phi)$. The results showed the beneficial effects of addition of fly ash to silt and sand. Addition of fly ash decreased the MDD of the soil. A fly ash-soil fill would therefore be lighter than a soil fill. The shear strength parameters of the fly ash-soil specimens were generally more than those of the soils. The fly ash-soil fill would therefore be stronger than the soil fill.

Table 2 Specific gravity and grain sizes of sand and silt [18]

\begin{tabular}{lcc}
\hline \multicolumn{1}{c}{ Properties } & Silt & Sand \\
\hline Specific gravity & 2.64 & 2.66 \\
Particle size & & \\
Fine sand size, $0.475-0.075 \mathrm{~mm}$ & $14 \%$ & $94 \%$ \\
Silt size, $0.075-0.002 \mathrm{~mm}$ & $73 \%$ & $6 \%$ \\
Clay size, less than $0.002 \mathrm{~mm}$ & $13 \%$ & - \\
\hline
\end{tabular}


Triaxial shear tests were carried out on OMC-MDD Dadri fly ash specimens also. The results of these tests were: UCS = $116.7 \mathrm{kPa} ; c_{u u}=12.6 \mathrm{kPa}, \phi_{u u}=31^{\circ}$; and $c^{\prime}=0, \phi^{\prime}=29.3^{\circ}[21]$.

Consolidation test and falling head permeability test were carried out on the same OMC-MDD Dadri fly ash specimen in a Casagrande type consolidometer. This experiment facilitated the investigation of the consolidation characteristics and the influence of the head loss across the specimen, effective stress, and void ratio on the coefficient of permeability $(k)$. Figure 2 shows the variation of $k_{a v}$ with vertical effective stress $\left(\sigma^{\prime}\right)$. $k$ decreased by $21.6 \%$ when $\sigma^{\prime}$ varied from 9.81 to $1255.68 \mathrm{kPa}$ [25]. However, $k$ was still in the range for non-plastic silts. This showed that fly ash embankments and fills would be moderately permeable over their entire height.

Table 3 Results of compaction, unconfined compression, and direct shear tests on fly ash-soil mixtures [18]

\begin{tabular}{ccccccc}
\hline $\begin{array}{c}\text { Mix } \\
\text { designation }\end{array}$ & $\begin{array}{c}\text { Fly ash-soil } \\
\text { mixture }\end{array}$ & $\begin{array}{c}M D D \\
\mathrm{kN} / \mathrm{m}^{3}\end{array}$ & $\begin{array}{c}O M C \\
\%\end{array}$ & $\begin{array}{c}\mathrm{UCS} \\
\mathrm{kPa}\end{array}$ & $\begin{array}{c}c \\
\mathrm{kPa}\end{array}$ & $\phi^{\circ}$ \\
\hline$R$ & Rajghat fly ash & 10.52 & 36.5 & 65.7 & 19.6 & 37.5 \\
$R M 1$ & $75 \% R+25 \% M$ & 12.21 & 26.6 & 61.7 & 13.7 & 37.0 \\
$R M 2$ & $50 \% R+50 \% M$ & 13.54 & 22.6 & 47.1 & 14.7 & 36.0 \\
$R M 3$ & $25 \% R+75 \% M$ & 15.40 & 18.0 & 50.6 & 22.6 & 30.5 \\
$M$ & Silt & 17.66 & 14.0 & 36.3 & 15.7 & 29.5 \\
$R S 1$ & $75 \% R+25 \% S$ & 11.92 & 28.6 & 44.1 & 18.6 & 34.0 \\
$R S 2$ & $50 \% R+50 \% S$ & 13.64 & 22.6 & 33.3 & 9.8 & 33.0 \\
$R S 3$ & $25 \% R+75 \% S$ & 15.11 & 17.5 & 20.6 & 21.6 & 31.5
\end{tabular}

No tests were carried out on sand as compaction tests are not applicable to sands.

\section{B. Baumineral Fly Ash-Rhine Sand Mixtures}

Experiments were also carried out on mixtures of a German fly ash and Rhine sand. The fly from a chemical manufacturing industry Baumineral near Bochum was mixed with fine sand deposited by Rhine River. The specific gravity of the Baumineral fly ash $G=2.36$, was higher than the $G$ of the two Indian fly ashes, probably due to the higher iron oxide content $(7.66 \%)$ of the Baumineral fly ash. The Baumineral fly ash too was a class $F$ fly ash as its lime $(\mathrm{CaO})$ content was only $0.21 \%$. The Rhine sand was slightly coarser than the sand used with the Rajghat fly ash. It had coarse sand size, medium sand size, fine sand size, and silt size contents of $1 \%, 16 \%, 82 \%$, and 1\%, respectively. Table 4 shows the results of experiments carried out on Baumineral fly ash-Rhine sand mixtures. The results show that Baumineral fly ash-Rhine sand mixtures had significantly greater $M D D$ values than the Rajghat fly ash-soil mixtures, probably due to the higher specific gravity of the Baumineral fly ash. As a result of this, the Baumineral fly ash-Rhine sand mixtures also had significantly greater $U C S$ values than the Rajghat fly ash-soil mixtures.

Table 4 Results of tests carried out on Baumineral fly ash-Rhine sand mixtures [18]

\begin{tabular}{ccccccc}
\hline $\begin{array}{c}\text { Mix } \\
\text { designation }\end{array}$ & Fly ash-soil mixture & $\begin{array}{c}M D D \\
\mathrm{kN} / \mathrm{m}^{3}\end{array}$ & $\begin{array}{c}O M C \\
\%\end{array}$ & $\begin{array}{c}\mathrm{UCS} \\
\mathrm{kPa}\end{array}$ & $\begin{array}{c}c \\
\mathrm{kPa}\end{array}$ & $\phi^{\circ}$ \\
\hline$B$ & Baumineral fly ash & 14.18 & 18.4 & 165.5 & 28.4 & 30.0 \\
$B S 1$ & $75 \% B+25 \% S$ & 16.09 & 13.0 & 146.4 & 26.5 & 38.0 \\
$B S 2$ & $50 \% B+50 \% S$ & 17.95 & 10.0 & 133.7 & 23.5 & 37.0 \\
$B S 3$ & $25 \% B+75 \% S$ & 18.98 & 8.2 & 50.6 & 11.8 & 34.0 \\
$S$ & Rhine sand & \multicolumn{4}{c}{ No tests were carried out on Rhine sand }
\end{tabular}

\section{FLY ASHES STABILIZED WITH FIBERS}

Experiments were carried out to investigate the influence of randomly oriented fiber inclusions on the geotechnical behavior of Rajghat and Dadri fly ashes. Figure 3 shows the scanning electron micrograph of the 6 mm long polyester fiber. Table 5 shows the other details of the fibers. Fiber content, $f_{c}$, in a fly ash-fiber mixture is defined as $f_{c}=W_{f} / W_{s}$, where $W_{f}=$ weight of fiber and $W_{s}=$ weight of dry fly ash. In Rajghat fly ash specimens $f_{c}=0.5$ and $1 \%$ were used whereas only $f_{c}=1 \%$ was used in Dadri fly ash specimens. Similarly, both 6 and $20 \mathrm{~mm}$ long fibers were used in Rajghat fly ash and only $6 \mathrm{~mm}$ long fibers were used in Dadri fly ash. Standard Proctor compaction tests, unconfined compression tests and triaxial shear tests, on OMC-MDD fly ash-fiber specimens, were conducted. Table 6 shows the results of the various tests. 
UNIMAS E-Journal of Civil Engineering, Vol. 3 (Special Issue) 2012

Table 5 Characteristics of fibers [23]

\begin{tabular}{lcccccc|}
\hline Type and color & $\begin{array}{c}\text { Diameter } \\
\mathrm{mm}\end{array}$ & $\begin{array}{c}\text { Length } \\
\mathrm{mm}\end{array}$ & $\begin{array}{c}\text { Aspect } \\
\text { ratio }\end{array}$ & $\begin{array}{c}\text { Specific } \\
\text { gravity }\end{array}$ & $\begin{array}{c}\text { Tensile strength } \\
\text { Mpa }\end{array}$ & $\begin{array}{c}\text { Tensile modulus } \\
\text { Mpa }\end{array}$ \\
\hline Polyester (Black) & 0.0203 & 6 & 313 & 1.38 & 510 & - \\
Polyester (Grey) & $\approx 0.075$ & 20 & 267 & 1.30 & $80-170$ & $1450-2500$ \\
\hline
\end{tabular}

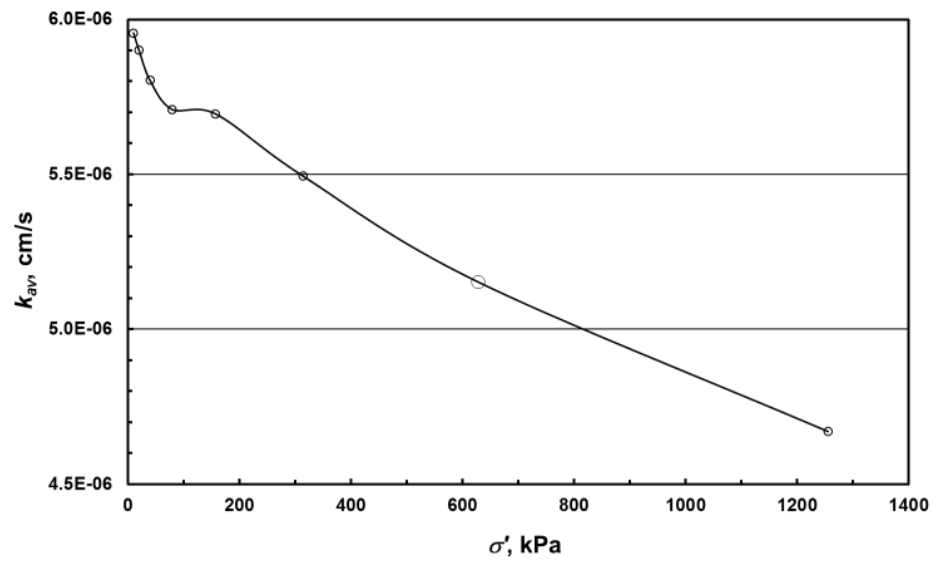

Figure 2 Variation of $k_{a v}$ with $\sigma^{\prime}$ [25]

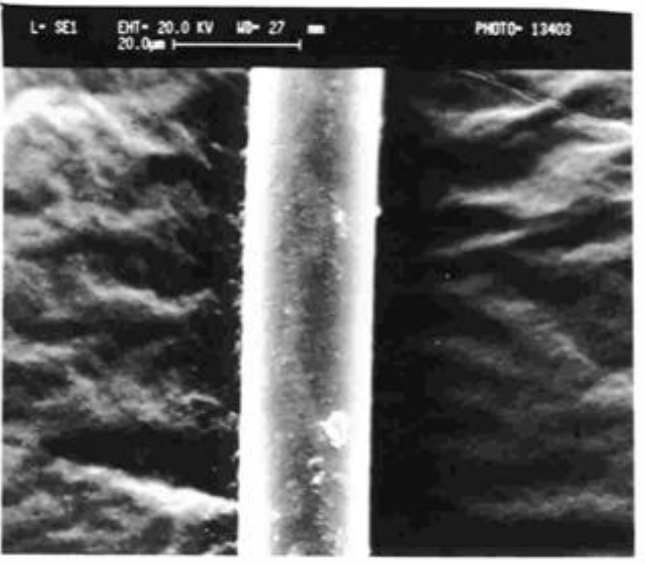

Figure 3 SEM of $6 \mathrm{~mm}$ polyester fiber [23]

Table 6 Results of compaction, unconfined compression, and triaxial shear tests on fly ash-fiber mixtures [23]

\begin{tabular}{|c|c|c|c|c|c|c|c|c|c|}
\hline Fly ash & $\begin{array}{l}f_{c} \\
\%\end{array}$ & $\begin{array}{l}\text { Fiber length } \\
\mathrm{mm}\end{array}$ & $\begin{array}{l}\mathrm{MDD} \\
\mathrm{kN} / \mathrm{m}^{3}\end{array}$ & $\begin{array}{c}\text { OMC } \\
\%\end{array}$ & $\begin{array}{l}\mathrm{UCS} \\
\mathrm{kPa}\end{array}$ & $\begin{array}{c}c_{u u} \\
\mathrm{kPa}\end{array}$ & $\phi_{u u}{ }^{\circ}$ & $\begin{array}{c}c^{\prime} \\
\mathrm{kPa}\end{array}$ & $\phi^{\text {o }}$ \\
\hline Dadri & - & - & 13.8 & 21 & 116.7 & 12.6 & 31 & 0 & 29.3 \\
\hline Rajghat & - & - & 10.5 & 37 & 65.7 & 43.2 & 30.1 & - & - \\
\hline Dadri & 1 & 6 & 13.8 & 22 & 181 & 93.7 & 32.5 & 55.9 & 33.6 \\
\hline Rajghat & 1 & 6 & 10.7 & 34 & 180.2 & 102.8 & 36 & - & - \\
\hline Rajghat & 1 & 20 & 11.0 & 33 & 157.9 & 128.6 & 36 & - & - \\
\hline Rajghat & 0.5 & 20 & 11.0 & 32 & - & - & - & - & - \\
\hline
\end{tabular}

The small fiber content did not affect the MDD and OMC of Dadri fly ash appreciably. In Rajghat fly ash, however, the effect was a little more marked; the fibers increased the MDD and decreased the OMC. The fiber inclusions had a highly favorable effect on shear strength of the raw fly ashes. They increased the UCS as well as the shear strength parameters $c$ and $\phi$ in the triaxial shear tests. The most significant effect of the fibers was on the stress-strain behavior of the fly ashes. Figure 4 shows the stress-strain curves in unconfined compression tests. Similar behavior was seen in other triaxial shear tests also. The fibers changed the brittle behavior of the raw fly ashes to ductile behavior.

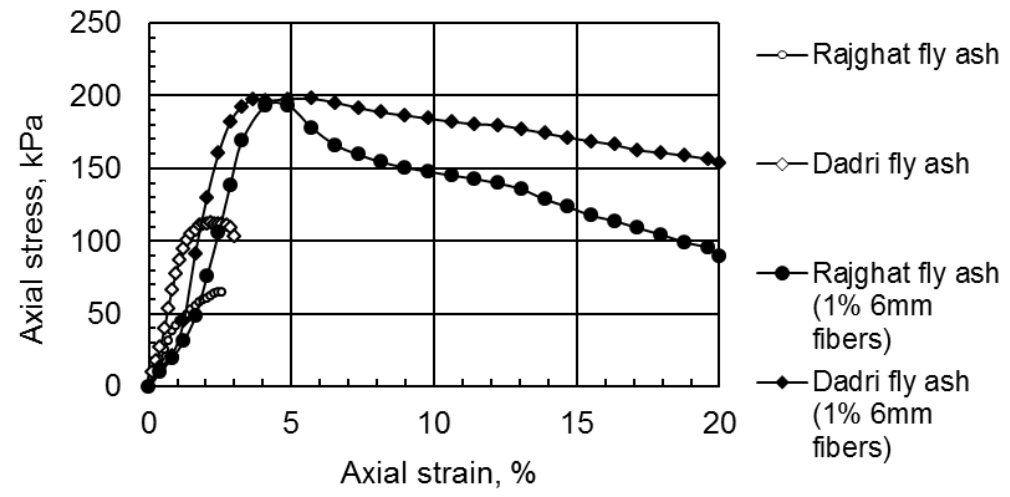

Figure 4 Stress-strain curves of fly ash-fiber specimens in unconfined compression tests [23] 


\section{RAJGHAT FLY ASH - SOIL MIXTURES STABILIZED WITH FIBERS}

Experiments were carried out to study the influence of randomly oriented fiber inclusions on the geotechnical behavior of selected Rajghat fly ash-soil mixtures. $20 \mathrm{~mm}$ long fibers (Table 5) and $f_{c}=1 \%$ were used. Table 7 shows the results of the compaction tests, unconfined compressive strength (UCS) and direct shear tests $(c, \phi)$ for the fiber reinforced fly ash-soil mixtures. The corresponding results for fly ash-soil mixtures without fibers are shown in Table 3. The results of unconsolidated undrained tests for the fiber reinforced fly ash-soil mixtures are also shown in Table 7. The corresponding values for fly ash-soil mixtures without fibers are shown alongside within parentheses.

Table 7 Results of compaction, unconfined compression, and direct shear tests on fiber reinforced fly ash-soil mixtures [22]

\begin{tabular}{ccccccccc}
\hline $\begin{array}{c}\text { Mix } \\
\text { designation }\end{array}$ & $\begin{array}{c}\text { Fly ash-soil } \\
\text { mixture }\end{array}$ & $\begin{array}{c}M D D \\
\mathrm{kN} / \mathrm{m}^{3}\end{array}$ & $\begin{array}{c}O M C \\
\%\end{array}$ & $\begin{array}{c}\mathrm{UCS} \\
\mathrm{kPa}\end{array}$ & $\begin{array}{c}c \\
\mathrm{kPa}\end{array}$ & $\phi^{\circ}$ & $\begin{array}{c}c_{u и} \\
\mathrm{kPa}\end{array}$ & $\phi_{\text {uи }}$ \\
\hline \multirow{2}{*}{$R M 2$} & $50 \% R+50 \% M$ & 13.90 & 23.0 & 304.0 & 32.5 & 35.1 & $\begin{array}{c}93.3 \\
(25.8)\end{array}$ & $\begin{array}{c}(30.0 \\
(30.2)\end{array}$ \\
& & & & & & & 160.0 & 32.9 \\
$R S 2$ & $50 \% R+50 \% S$ & 13.60 & 23.5 & 436.4 & 17.4 & 39.4 & $\begin{array}{c}(16.5) \\
(30.4)\end{array}$ \\
$M$ & Silt & 17.60 & 14.5 & 411.9 & 21.3 & 38.4 & - & - \\
\hline
\end{tabular}

Fibers did not have a significant effect on OMC and MDD of the fly ash-soil mixtures. However, they increased the shear strength of the fly ash-soil mixtures. The relative gain in UCS was defined as $G_{f}=\left(q_{f o}-q_{o}\right) / q_{o}$, where $q_{o}$ and $q_{f o}$ are the UCS of the unreinforced and fiber-reinforced specimens, respectively. The relative gain in UCS of RM2 and RS2 were as high as $546 \%$ and $1,211 \%$, respectively. As in the case of raw fly ashes, the fibers changed the behavior of the fly ash-soil mixtures also from brittle to ductile.

\section{FLY ASH - SOIL MIXTURES STABILIZED WITH CEMENT}

Two series of investigations were carried out to study the effect of ordinary Portland cement as a stabilizing agent of fly ash-soil mixtures. Cement content, $C_{C}$, was defined as $C_{C}=W_{C} / W_{A S}$, where $W_{C}=$ weight of cement and $W_{A S}=$ weight of dry fly ash-soil mixture. In the first series (Series I) of experiments small cement contents of $C_{C}=3 \%$ and $6 \%$ were used. In general, $37.7 \times 73.5 \mathrm{~mm}$ cylindrical specimens were prepared at the OMC-MDD state of the fly ash-soil mixtures, wrapped individually in a polyethylene bag, and kept inside a desiccator with a little quantity of water at the bottom of the desiccator and the temperature maintained around $21^{\circ} \mathrm{C}$, for curing of the specimens. At the end of the specified curing period, unconfined compression tests were carried out. Table 8 shows the results for Series I experiments. The cement content did not influence the initial $(t=0)$ UCS of the specimens. The initial values of UCS can be referred to in Table 3 . Even small cement contents increased the UCS of all fly ash-soil specimens significantly. The cement stabilized fly ash-soil specimens showed brittle behavior and the failure strain was in the range of $1-2 \%$.

Table 8 UCS (kPa) of fly ash-soil mixtures stabilized with cement and fibers - Series I [22]

\begin{tabular}{|c|c|c|c|c|c|c|c|}
\hline \multirow{3}{*}{$\begin{array}{c}\text { Mix } \\
\text { designation }\end{array}$} & \multirow{3}{*}{$\begin{array}{l}\text { Fly ash-soil } \\
\text { mixture }\end{array}$} & \multicolumn{6}{|c|}{ Curing period (days) } \\
\hline & & \multicolumn{2}{|c|}{$\begin{aligned} C_{C} & =3 \% \\
f_{c} & =0\end{aligned}$} & \multicolumn{2}{|c|}{$\begin{array}{c}C_{C}=6 \% \\
f_{c}=0\end{array}$} & \multicolumn{2}{|c|}{$\begin{array}{l}C_{C}=3 \% \\
f_{c}=1 \%{ }^{\mathrm{a}}\end{array}$} \\
\hline & & 7 & 28 & 7 & 28 & 7 & 28 \\
\hline$R$ & Rajghat fly ash & 138.3 & 271.7 & 483.5 & 918.9 & 218.7 & 389.3 \\
\hline$R M 1$ & $75 \% R+25 \% M$ & 219.7 & 251.1 & 589.5 & 893.4 & - & - \\
\hline$R M 2$ & $50 \% R+50 \% M$ & 310.9 & 394.5 & 724.2 & $1,127.5$ & 769.8 & 866.9 \\
\hline$R M 3$ & $25 \% R+75 \% M$ & 433.5 & 750.3 & 821.1 & $1,155.5$ & - & - \\
\hline$M$ & Silt & 650.5 & 931.6 & $1,013.3$ & $1,678.2$ & 1,220 & 1,350 \\
\hline$R S 1$ & $75 \% R+25 \% S$ & 123.6 & 211.8 & 259.9 & 728.6 & - & - \\
\hline$R S 2$ & $50 \% R+50 \% S$ & 135.3 & 270.7 & 272.6 & 822.8 & 482.5 & 680.6 \\
\hline$R S 3$ & $25 \% R+75 \% S$ & 115.7 & 341.3 & 291.3 & 753.2 & 687.5 & 757.1 \\
\hline
\end{tabular}

A fly ash-stabilizer design mix for base courses is one that complies with the prescribed strength criteria. In the second series (Series II) of experiments, utilization of fly ash as a base course material in pavements was investigated. Larger cement contents complying with the criteria of Electric Power Research Institute (EPRI) [28] were used. The tests were carried out only on the two raw fly ashes. The EPRI criteria are: (1) the minimum UCS of the specimens after 7 days of curing should be in the range of 2760-3100 kPa and should not exceed $5500 \mathrm{kPa}$; (2) UCS must increase with time; the 28 day UCS is approximately twice that of the 7-day UCS; and (3) during curing, the specimens are wrapped in moisture proof 
bags and kept under $21 \pm 2^{\circ} \mathrm{C}$. The design mix was determined by compaction tests and unconfined compression tests on trial mixes. The final design mix specifications were $C_{c}=18 \%$, water content $(w)=\mathrm{OMC}=37 \%$ and dry unit weight $\left(\gamma_{d}\right)=\mathrm{MDD}$ $=11.7 \mathrm{kN} / \mathrm{m}^{3}$ for Rajghat fly ash specimens and $C_{c}=15 \%, w=0.85 \mathrm{~S}=23.6 \%$, and $\gamma_{d}=0.95 \mathrm{MDD}=13.74 \mathrm{kN} / \mathrm{m}^{3}$ for Dadri fly ash specimens. $S$ is the degree of saturation. The development of the cementation products in Dadri fly ash can be seen in the scanning electron micrographs in Figure 5. Table 9 shows the UCS values for the Rajghat and Dadri fly ash design mix specimens of above specifications. The specimens failed suddenly after reaching the peak stress. The average failure strain varied between 1 and $3.5 \%$.

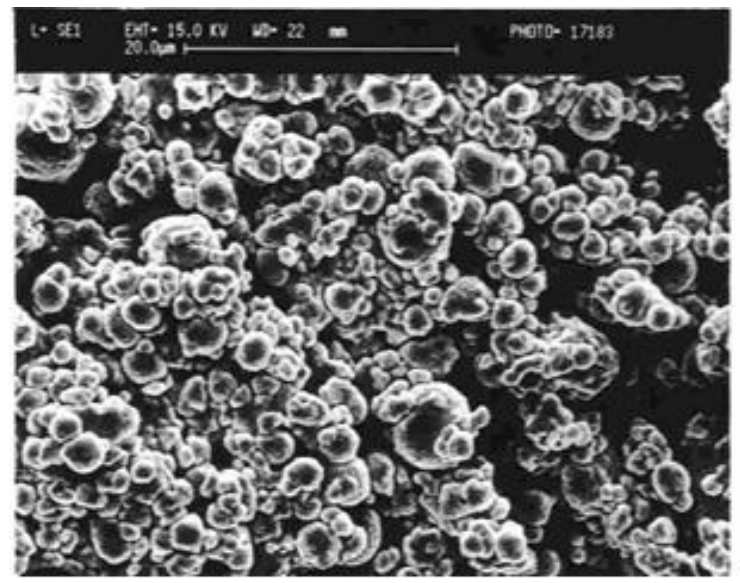

(a)

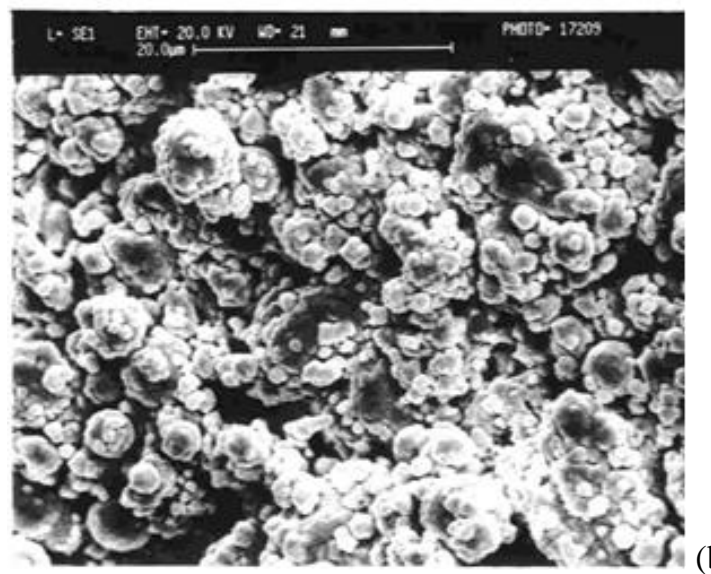

(b)

Figure 5 SEM of cement stabilized Dadri fly ash (Series II): (a) 7 days curing, and (b) 28days curing [24]

Table 9 UCS (kPa) of fly ashes stabilized with cement and fibers - Series II [24]

\begin{tabular}{lccccc}
\hline \multirow{2}{*}{ Fly ash } & \multicolumn{4}{c}{ Curing period (days) } \\
\cline { 2 - 6 } & 0 & 7 & 28 & 7 & 28 \\
\cline { 2 - 5 } & 120.6 & 3,843 & 7,453 & 3,389 & 7,749 \\
\hline Rajghat fly ash & 116.7 & 3,172 & 3,689 & 3,481 & 6,026 \\
Dadri fly ash & \multicolumn{4}{c}{$f_{c}=0$} & \multicolumn{4}{c}{${ }^{\mathrm{a}}$} \\
\hline \multicolumn{4}{c}{$6 \mathrm{~mm}$ long polyester fibers (Table 5) }
\end{tabular}

\section{FLY ASH - SOIL MIXTURES STABILIZED WITH CEMENT AND FIBERS}

On the fly ash-soil mixtures stabilized with fibers alone and cement alone explained before, another set of experiments were done in which the fly ash-soil mixtures were stabilized with both cement and fibers. Figure 6 shows the scanning electron micrograph of Rajghat fly ash stabilized with both cement and fibers.

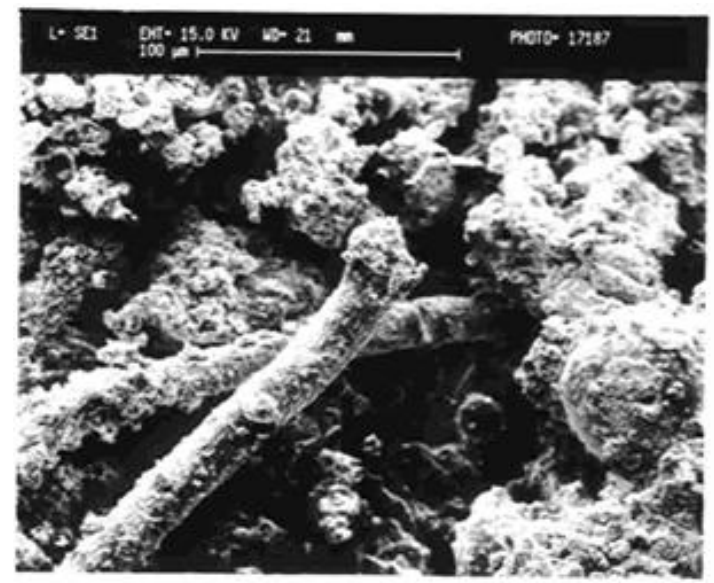

Figure 6 SEM of cement and fiber stabilized Rajghat fly ash - Series II (28days curing) [24]

The UCS values of the cement and fiber stabilized specimens are shown alongside the respective UCS values of the specimens stabilized with cement alone in Tables 8 and 9 for Series I and Series II experiments, respectively. Some typical stress-strain curves of Series II experiments are shown in Figure 7. Each curve in the figure is for a particular combination of fly ash, cement content, and fiber length. RA and DA in the legend denote Rajghat fly ash and Dadri fly ash, respectively. The second figure of 18 and 15 denote the cement content. The third figure 06, 09, and 20 mm denote the length of fibers 
used. The value of 00 in the third figure indicates that the specimen was stabilized only with cement and no fiber was used. The addition of fibers increased the UCS of cement stabilized Dadri fly ash significantly whereas it did not have a significant effect on the UCS of Rajghat fly ash. Like the cement stabilized fly ash specimens, the cement and fiber stabilized fly ash specimens of Series II too failed suddenly after reaching the peak stress. However, the fibers increased the failure strain; the average failure strain varied between 2.5 and $4.5 \%$.

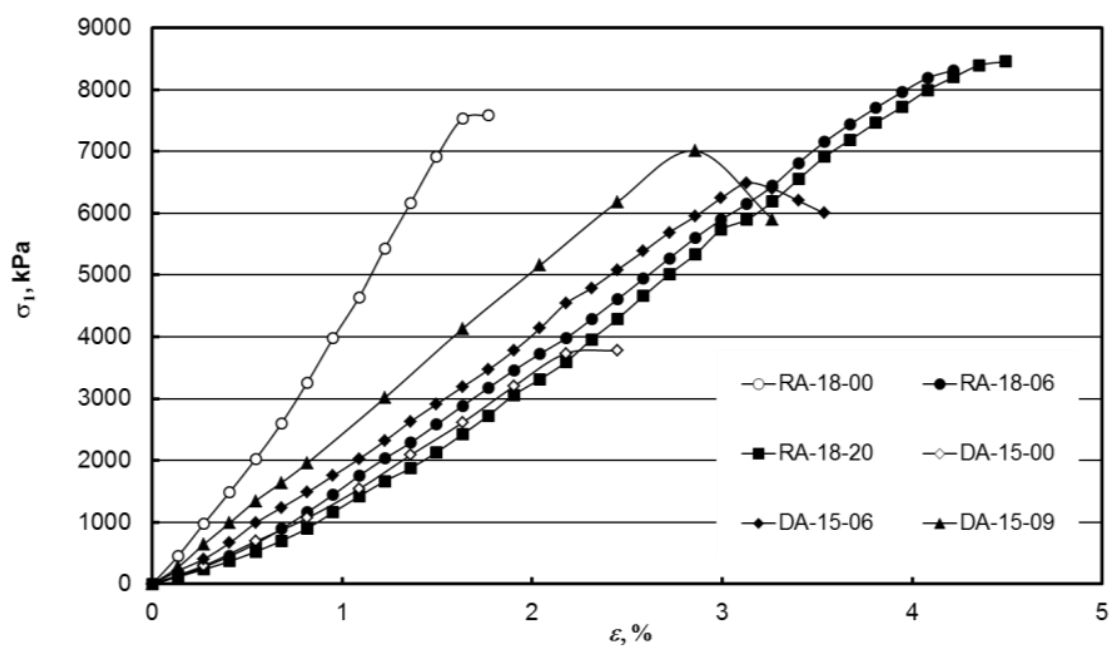

Figure 7 Axial stress-strain curves of cement and fiber stabilized fly ash specimens cured for 28 days [26]

\section{CONCLUSIONS}

Following conclusions are arrived at from the experimental studies.

1. Mixing fly ash with soil decreased the MDD of soil. A fly ash-soil fill would therefore be lighter than a soil fill. The shear strength parameters of fly ash-soil fill were generally more than those of the soil fill. The fly ash-soil fill would therefore be stronger than the soil fill. Further, fly ash embankments and fills would be moderately permeable over their entire height.

2. In general, polyester fiber inclusions did not have a significant effect on the MDD and OMC of raw fly ashes and fly ash-soil mixtures. But, fiber inclusions had a highly favorable effect on shear strength and shear behavior. They increased the UCS as well as the shear strength parameters of the raw fly ashes and fly ash-soil mixtures. The fibers also changed the stress-strain behavior of the specimens from brittle to ductile.

3. Even small cement contents increased the UCS of the fly ash-soil specimens significantly. With higher cement contents of up to $18 \%$ it was possible to prepare fly ash-cement design mixes that satisfied the strength criteria for pavement base courses. All cement stabilized fly ash and fly ash-soil specimens failed suddenly after reaching the peak stress.

4. The addition of fibers increased the UCS of the cement stabilized Dadri fly ash significantly whereas it did not have a significant effect on the UCS of the cement stabilized Rajghat fly ash. The cement and fiber stabilized fly ash specimens too failed suddenly after reaching the peak stress. However, the fibers increased the failure strain.

\section{ACKNOWLEDGMENT}

The authors acknowledge with thanks the use of facilities at the Indian Institute of Technology, Delhi, where the experiments were carried out. The financial support provided by Universiti Malaysia Sarawak, Kota Samarahan, Sarawak, for this paper is also acknowledged with thanks.

\section{REFERENCES}

[1] D. H. Gray, "Role of woody vegetation in reinforcing soils and stabilizing slopes," in Proc. Symp. on Soil Reinforcement and Stabilizing Techniques, Sydney, Australia, 1970, pp. 253-306.

[2] C. B. Brown and M. S. Sheu, "Effect of deforestation on slopes," J Geotech. Eng. Div., ASCE, vol. 101, GT1, pp. 147-165, 1975.

[3] L. J. Waldron, "Shear resistance of root-permeated homogeneous and stratified soil", Soil Science Society of America J., vol. 41 , pp. 843-849, 1977.

[4] T. H. Wu and R. T. Erb, "Study of soil-root interaction," J Geotech. Eng. Div., ASCE, vol. 114, no. 12, pp. 1351-1375, 1988.

[5] T. H. Wu, P. E. Beal and C. Lan, "In-situ shear test of soil-root system," J Geotech. Eng. Div., ASCE, vol. 114, no. 12, pp. 1376-1394, 1988.

[6] A. McGown, K. Z. Andrawes and M. M. Al-Hasani, "Effect of inclusion properties on the behaviour of sand," Geotechnique, vol. 28, no. 3, pp. 327$346,1978$.

[7] S. S. Rehsi, "Use of natural fibre concrete in India," in Natural Fibre Reinforced Cement and Concrete, (ed) R.N. Swamy, Blackie-Glassy, 1988.

[8] R. M. Vasan, "Investigations on fibre reinforced concrete pavements," Ph.D. Thesis, University of Roorkee, Roorkee, India, 1989.

[9] D. H. Gray and H. Ohashi, "Mechanics of fiber reinforcing in sand," J Geotech. Eng. Div., ASCE, vol. 109, no. 3, pp. 335-353, 1983.

[10] S. E. Shewbridge and N. Sitar, "Deformation characteristics of reinforced soil in direct shear," J Geotech. Eng. Div., ASCE, vol. 115, no. 8, pp. 11341147, 1989. 
[11] G. E. Bauer and M. N. Fatani, "Strength characteristics of sand reinforced with rigid and flexible elements," in Proc. 9th Asian Regional. Conf. on Soil Mech. Found. Eng., Bangkok, vol. 1, pp. 471-474, 1991.

[12] D. J. Hoare, "Laboratory study of granular soils reinforced with randomly oriented discrete fibers," in Proc. Int. Conf. on Soil Reinforcement, Paris, France, vol. 1, pp. 47-52, 1979.

[13] M. H. Maher, "Static and dynamic response of sands reinforced with discrete randomly distributed fibers," Ph.D. Thesis, University of Michigan, Ann Arbor, U.S.A., 1988.

[14] D. H. Gray and M. H. Maher, "Admixture stabilization of sand with discrete randomly distributed fibers," in Proc. XII Int. Conf. on Soil Mech. Found. Eng., Rio de Janeiro, Brazil, pp. 1363-1366, 1989.

[15] M. H. Maher and D. H. Gray, "Static response of sands reinforced with randomly distributed fibers," J Geotech. Eng. Div., ASCE, vol. 116, no. 11, pp. 1661-1677, 1990.

[16] H. D. Charan, "Probabilistic analysis of randomly distributed fibre reinforced soil," Ph.D. Thesis, University of Roorkee, Roorkee, India, 1995.

[17] D. K. Chakraborty and S. P. Dasgupta, "Randomly reinforced fly ash foundation material," in Indian Geotechnical Conference, Madras, vol. 1, pp. 231-235, 1996

[18] S. R. Kaniraj and V. G. Havanagi, “Geotechnical characteristics of fly ash-soil mixtures,” Geotechnical Eng. J., vol. 30, no. 2, pp. 129-147, Aug. 1999.

[19] S. R. Kaniraj and V. G. Havanagi, “Compressive strength of cement stabilized fly ash-soil mixtures,' Concrete and Cement Research, vol. 29, pp. 673-677, 1999.

[20] S. R. Kaniraj and V. G. Havanagi, "Correlation analysis of laboratory compaction of fly ashes," Practice Periodical of Hazardous, Toxic, and Radioactive Waste Management, vo. 5, no. 1, Jan. 2001.

[21] S. R. Kaniraj and V. Gayathri, "Geotechnical behavior of fiber reinforced fly ash," in Landmarks in Earth Reinforcement, Ochiai et al, Ed. 2001, pp. 61-65.

[22] S. R. Kaniraj and V. G. Havanagi, "Behavior of cement-stabilized fiber-reinforced fly ash-soil mixtures,' J. Geotechnical and Geoenvironmental Eng., vo. 127 , no. 7 , pp. 574-584, July 2001.

[23] S. R. Kaniraj and V. Gayathri, "Geotechnical behavior of fly ash mixed with randomly oriented fiber inclusions," Geotextiles and Geomembranes, vol. 21, pp. 123-149, 2003.

[24] S. R. Kaniraj and V. Gayathri, "Factors influencing the strength of cement fly ash base courses," J. Transp. Eng., vol. 129, no. 5, pp. 538-548, 2003.

[25] S. R. Kaniraj and V. Gayathri, "Permeability and consolidation characteristics of compacted fly ash," J. Energy Eng., vol. 130, no. 1, pp. 18-43, April 2004.

[26] S. R. Kaniraj and V. Gayathri, "Behavior of fiber-reinforced cement-stabilized fly ashes," J. Testing and Evaluation, vol. 34, no. 4, pp. 290-297, July 2006.

[27] ASTM Standard C 618, "Specification for fly ash and raw or calcined natural pozzolana for use as a mineral admixture in Portland cement concrete," in Annual Book of ASTM Standards, sec. 4, vol. 4.02, pp. 310-312, 1993.

[28] P. E. Glogowski, J. M. Kelly, R. J. McLaren, and D. L. Burns, "Fly ash design manual for road and site application," Final rep. prepared for Electric Power Research Institute, Palo Alto, Calif., 1992. 